\title{
Incorporation of $\mathrm{TiO}_{2}$ into the $\mathrm{PtPd} / \mathrm{C}$ Catalyst Layer for Improvement ORR Activity and Water Management
}

\author{
Nutthaphak Kitiphatpiboon ${ }^{1}$, Mali Hunsom ${ }^{1,2 . *}$ \\ ${ }^{1}$ Fuels Research Center, Department of Chemical Technology, Faculty of Science, Chulalongkorn \\ University, 254 Phayathai Road, Bangkok 10330, Thailand. \\ ${ }^{2}$ Center of Excellence on Petrochemical and Materials Technology (PETRO-MAT), Chulalongkorn \\ University, 254 Phayathai Road, Bangkok 10330, Thailand \\ *E-mail: mali.h@chula.ac.th
}

doi: $10.20964 / 110402741$

Received: 4 January 2016 / Accepted: 29 January 2016 / Published: 1 March 2016

Titanium dioxide $\left(\mathrm{TiO}_{2}\right)$ samples prepared by different thermal treatments were incorporated in the cathode catalyst layer of a polymer electrolyte membrane or proton exchange membrane (PEM) fuel cell. Increasing the $\mathrm{TiO}_{2}$ treatment temperature $\left(500-800{ }^{\circ} \mathrm{C}\right.$ for $3 \mathrm{~h}$ ) resulted in an increased rutile phase content and crystal size, but decreased textural properties of the obtained $\mathrm{TiO}_{2}$. Incorporation of $\mathrm{TiO}_{2}$ prepared at the appropriate temperature in the carbon-supported $\mathrm{PtPd}$ catalyst $(\mathrm{PtPd} / \mathrm{C})$ layer positively affected the catalyst dispersion, electrochemical surface area and electrical conductivity of catalyst layer, but did not affect the electron pathway of the oxygen reduction reaction (ORR) of $\mathrm{PtPd} / \mathrm{C}$ catalysts. Overall, the $\mathrm{PtPd} / \mathrm{C}$ catalyst with $\mathrm{TiO}_{2}$ calcined at $800{ }^{\circ} \mathrm{C}\left(\mathrm{T}_{800}-\mathrm{PtPd} / \mathrm{C}\right)$ exhibited the highest ORR activity $\left(\sim 486 \mathrm{~mA} / \mathrm{cm}^{2}\right.$ at $\left.0.6 \mathrm{~V}\right)$ both in an acid solution and in a PEM fuel cell under a $\mathrm{H}_{2} / \mathrm{O}_{2}$ environment at atmospheric pressure compared to those for the $\mathrm{Pt} / \mathrm{C}, \mathrm{PtPd} / \mathrm{C}$ and the other $\mathrm{TiO}_{2^{-}}$ $\mathrm{PtPd} / \mathrm{C}$ catalysts.

Keywords: $\mathrm{TiO}_{2}, \mathrm{PtPd} / \mathrm{C}$ catalyst; ORR activity; PEM fuel cell

\section{$\underline{\text { FULL TEXT }}$}

(C) 2016 The Authors. Published by ESG (www.electrochemsci.org). This article is an open access article distributed under the terms and conditions of the Creative Commons Attribution license (http://creativecommons.org/licenses/by/4.0/). 